\title{
Analisis Deskriptif Tingkat Kepercayaan Pelanggan PT. Telekomunikasi Indonesia, Tbk Berdasarkan Dimensi Integrity
}

(Studi pada Pendukung Petisi Online IndiHome di Change.org)

\author{
Imam Soedardji \\ Fakultas Ilmu Komunikasi \\ Universitas Pancasila \\ +6281288621654 | imam.soedardji1993@gmail.com \\ Diah Febrina \\ Dosen Fakultas Ilmu Komunikasi \\ Universitas Pancasila \\ +6281316345815|diah.febrina@gmail.com
}

\begin{abstract}
ABSTRAK
Pesatnya perkembangan internet mengubah cara PR terhubung dengan publiknya. Itu juga diikuti oleh kata "tanpa batas" yang berarti tidak terbatas pada pengguna untuk berdebat tentang produk atau layanan yang dapat mengakibatkan kerusakan kepercayaan yang telah didirikan selama bertahun-tahun oleh perusahaan dan publik mereka. Petisi tentang IndiHome di Change.org berarti jika pelanggan merasa kecewa dan tidak bisa lagi mempercayai Telkom. Penelitian ini menggunakan penelitian deskriptif kuantitatif dengan kuesioner sebagai instrumen penelitian dan didistribusikan kepada konsumen dan pendukung petisi tentang Indiome di Change.org. Data dianalisis menggunakan tabel distribusi frekuensi dan kemudian data dikode ulang menjadi tiga kategori. Temuan dalam penelitian ini adalah dimensi integritas adalah level sedang.
\end{abstract}

Kata kunci: hubungan masyarakat, kepercayaan, integritas, petisi online

\section{ABSTRACT}

The rapid development of the internet changes the way of public relations get connected with their public. It also followed by "borderless" word which means limitless on users to argue about a product or service that may result in damage to the trust that has been established for many years by the company and their publics. Petition about IndiHome on Change.org means if customers feel disappointed and can't longer believe Telkom. This study used quantitative descriptive research with questionnaire as a research instrument and distributed to consumers and supporter of petition about Indiome on Change.org. The data were analyzed using table of distribution of frequency and then the data recoded into three categories. The findings in this study were the dimension of integrity is moderate level.

Keyword: public relations, trust, integrity, petition online

\section{PENDAHULUAN}

Penetrasi pertumbuhan Internet di Indonesia menurut data dari internetworldstats.com sudah mencapai angka 88 juta pengguna atau 34\% dari total populasi pada tahun 2016. Fenomena tersebut memiliki dampak yang cukup signifikan bagi para praktisi public relations dalam menjalin hubungan dengan publiknya. Laksamana (2015) menjelaskan bahwa pada mulanya praktisi public relations menggunakan media konvensional, lalu beralih kepada media 
online yang dianggap lebih efisien dalam memberikan informasi terkait dengan perusahaan.

Tingginya pengguna Internet di Indonesia juga menandakan hilangnya batas dalam mengakses informasi, seperti halnya pernyataan Negroponte yang dikutip oleh Budiargo (2015) bahwa setiap perkembangan teknologi dan informasi akan selalu diikuti dengan kata "borderless" atau tidak ada batasan dalam mengakses informasi. Hal ini dapat mengakibatkan banyaknya opini negatif yang berkembang di dunia maya mengenai suatu produk atau jasa dari sebuah perusahaan, lebih lagi opini tersebut belum tentu benar adanya. Nova (2014) mengutarakan jika opini negatif yang berkembang di dunia maya akan menghasilkan publikasi di media tradisional, mengingat kecenderungan media tradisional saat ini lebih suka mengangkat isu yang ramai dibicarakan di dunia maya, didukung pula dengan banyaknya mediaonline yang diperuntukkan bagi para netizen untuk mengemukakan pendapat dan beropini seperti halnya membuat petisi online mengenai IndiHome di Change.org.

Petisi tersebut berisikan tentang kekecewaan mengenai kebijakan baru yang diterapkan oleh pihak PT. Telekomunikasi Indonesia, Tbk (selanjutnya disebut Telkom) mengenai fair usage policy (FUP) dan menghilangnya beberapa channel TV pada layanan UseeTV sehingga dianggap sangat merugikan para pelanggan. Pelanggan menilai harapan yang diberikan pada awal promo berbeda dengan kenyataan. Janji yang diberikan pada saat awal promo untuk layanan Internet adalah unlimited, sedangkan layanan UseeTV sebanyak 64 channel. Pada awal bulan Februari 2016 kebijakan tersebut berubah, mulai dari diterapkannya kebijakan FUP sebesar 300GB/Bulan hingga menghilangnya channel HBO dan FOX. Tidak hanya sampai disitu, pelayanan Telkom Care 147 dinilai juga tidak dapat membantu para pelanggan untuk mendapatkan klarifikasi yang jelas.

Pendukung petisi mengharapkan semua tuntutan yang disampaikan melalui petisi dapat dikabulkan, begitu pula dengan janji yang diberikan pada awal promo agar selalu dipenuhi oleh pihak Telkom. Pada kenyataanya, hanya ada satu tuntutan yang dicoba untuk diperbaiki, yaitu pelayanan Telkom Care 147 dan Telkom juga memberikan opsi, seperti: youtube yang tidak termasuk dalam FUP dan penambahan channel lainnya. Pengambilan keputusan yang diambil oleh Telkom tidak menutup kemungkinan akan menimbulkan penilaian negatif dan menurunnya tingkat kepercayaan di benak para pelanggan terhadap Telkom itu sendiri. Adanya 
penilaian negatif dan ketidak-jujuran yang dirasakan oleh pihak pelanggan ditenggarai dapat merusak integritas perusahaan, mengingat integritas merupakan salah satu faktor utama dalammembangun kepercayaan (Mayer et al., 1995).

Gambaran kasus diatas menjelaskan jika hubungan antara integritas dan kepercayaan itu sendiri melibatkan penilaian dari publik, bahwa perusahaan harus selalu menepati janji yang telah diberikan (Mayer et al., 1995). Mengacu dari sudut pandang public relations, kepercayaan adalah faktor penting dalam menjalin hubungan, karena kepercayaan dan nama baik perusahaan tidak dapat dibeli, melainkan dihasilkan melalui jangka waktu yang lama (Payne, 2012).

\section{TINJAUAN PUSTAKA}

\section{Public Relations dalam membentuk Kepercayaan}

Kebutuhan kepercayaan dalam praktek public relations sangat penting dan terdiri dari dua tingkat seperti yang diutarakan oleh Rawlins (2007). Pertama, untuk memenuhi peran sebagai utusan dari perusahaan, praktisi public relations harus memiliki kredibilitas. Kedua, kepercayaan sangat penting bagi public relations dengan tujuan utama untuk membangun dan mempertahankan hubungan dengan para stakeholder utama pada siapa keberhasilan dari perusahaan bergantung, pun-kepercayaan harus diukur dan dimasukkan sebagaiindikator penting bagi setiap perusahaan yang berkaitan dengan hubungan stakeholder dan reputasi. Berikut penjelasan mengenai kepercayaan dan kredibilitas serta kepercayaan didalam hubungan public relations yang diutarakan oleh Rawlins (2007):

a. Kepercayaan dan Kredibilitas

Public relations memiliki tugas yang biasanya memberikan informasi positif kepada publiknya. Peran kepercayaan di dalam hubungan ini sangat penting untuk membangung kredibiltas, salah satunya dengan pelanggan dan tentunya sesuai dengan target yang ingin dicapai. Pengertian dari kredibilitas itu sendiri merupakan keyakinan bahwa publik dapat mempercayai kebenaran dari pesan yang diberikan.

b. Kepercayaan di dalam hubungan Pekerjaan public relations masih bergantung kepada kredibilitas untuk berhubungan baik dengan para publiknya. Kepercayaan di dalam sebuah hubungan diibaratkan sebagai sebuah jantung dan kepercayaan merupakan alat 
yang dibutuhkan untuk mencapai hubungan yang lebih memuaskan.

Hubungan yang dijalin antara publik perusahaan dan perusahaan itu bila dilihat dari berbagai kegiatan bisnis dapat dikatakan cukup sederhana. Lain halnya dengan hubungan antara pelanggan perusahaan dengan public relations yang jauh lebih rumit. Sudah lama dikatakan bahwa kepercayaan (non transaksional) dijadikan acuan sebagai kesuksesan dalam kegiatan bisnis perusahaan, hal tersebut terjadi dikarenakan peran dari public relations untuk memberikan informasi mengenai perusahaan (Jordan, 2006).

\section{Integritas dalam membentuk Kepercayaan \\ Integritas merupakan salah satu} faktor dalam membangun kepercayaan. Merusak integritas sama halnya dengan merusak kepercayaan, maupun sebaliknya (Somera \& Holt, 2015). Integritas merupakan dimensi penting dalam konsep kepercayaan. Integritas dapat meramalkan kejadian yang akan datang dan selalu dikaitan dengan bagaimana perilaku atau kebiasaann perusahaan dalam menjalankan bisnisnya (Mayer, 1995). Informasi yang diberikan kepada publiknya apakah benar sesuai dengan fakta atau tidak. Kim et al. (2003) mengemukakan bahwa integrity dapat dilihat dari sudut pemenuhan (fulfillment), kejujuran (honestly), dan kehandalan (reliability).

Menjaga kepercayaan sangat penting bagi perusahaan. Timbulnya ketidakpercayaan dibenak publik jelas akan berakibat buruk bagi reputasi perusahaan. Hal ini tidak dapat lepas dari opini maupun review yang berkembang di dunia maya mengenai produk atau jasa dari perusahaan terkait. Paliszkiewicz \& Klepacki (2013) mengatakan bahwa diberbagai situasi kepercayaan dibangun dengan waktu yang lama, perusahaan membutuhkan interaksi yang intens kepada publiknya, maka dari itu penting bagi perusahaan untuk memenuhi kepentingan publiknya.

Charles Handy yang dikutip Oetomo et al (2008) menyebutkan dengan istilah trust and the virtual organizations yang dapat dibangun melalui seven rules of trust, yaitu:

a. Trust is not blind

Kepercayaan bukanlah sesuatu yang buta dapat diartikan bahwa loyalitas akan muncul dari dasar kepercayaan yang membutuhkan proses dan bukti nyata.

b. Trust need boundaries

Kepercayaan selalu memiliki batas. Sebuah kepercayaan dapat dibangun dengan adanya komitmen 
dan kemampuan yang harus dimiliki oleh perusahaan.

c. Trust demand learning Menjadi pihak yang dapat dipercaya memerlukan suatu proses pembelajaran yang panjang, maka dari itu kepercayaan merupakan proses.

d. Trust is tough

Menjalin dan menjaga sebuah kepercayaan tidaklah semudah membalikkan telapak tangan, butuh waktu dan proses panjang yang sulit. Terkait hal tersebut, perusahaan harus berhati-hati dalam membangun kepercayaan, apabila kepercayaan gagal diraih, dampaknya adalah harus keluar dari ruang lingkup bisnis yang dijalani.

e. Trust need bonding

Kepercayaan membutuhkan sebuah ikatan. Kepercayaan memiliki jalinan emosional yang memerlukan perhatian tersendiri, karena setiap tujuan memiliki fungsinya sendiri untuk mendukung tujuan lainnya yang lebih besar.

f. Trust need touch

Kepercayaan memerlukan sentuhan personal. Adanya campur tangan, baik dalam memberikan perhatian ataupun komunikasi yang baik akan membentuk jalinan kepercayaan.

\section{g. Trust requires leaders}

Kepercayaan memerlukan pemimpin. Peran pemimpin untuk menjadikan sesuatu dapat dipercaya adalah cukup dominan. Pemimpin ini berperan dalam mendesain dan mengupayakan tumbuh dan berkembangnya kepercayaan itu sendiri.

\section{METODOLOGI}

Penelitian ini didesain dengan menggunakan jenis deskriptif kuantitatif dengan kuesioner online sebagai instrumen penelitian. Ada 101 responden yang memiliki kriteria sebagai pendukung petisi sekaligus pelanggan IndiHome. Teknik analisis data yang digunakan adalah dengan tabel distribusi frekuensi yang kemudian di recode menjadi menjadi tiga kategori, yaitu tinggi, sedang, dan rendah. Tingkat kepercayaan diukur pada dimensi integritas (Meyer et al.,1995) yang mempunyai indikator tentang pemenuhan informasi, kejujuran dan kehandalan.

\section{HASIL DAN PEMBAHASAN}

Dari 101 responden yang mengisi kuesioner secara online ditemukan hasil yang ditunjukkkan pada tabel 1 sebagai berikut : 


\begin{tabular}{|c|l|c|c|c|c|c|}
\hline No. & \multicolumn{1}{|c|}{ Pernyataan } & STS & TS & S & SS & Total \\
\hline \multirow{2}{*}{1.} & TELKOM memberikan informasi sesuai & 6 & 25 & 9 & 61 & 101 \\
\cline { 3 - 7 } & dengan kebutuhan pelanggan & $5,9 \%$ & $24,8 \%$ & $8,9 \%$ & $60,4 \%$ & $100 \%$ \\
\hline \multirow{2}{*}{2.} & $\begin{array}{l}\text { TELKOM dapat memberikan pemenuhan } \\
\text { informasi kepada pelanggan }\end{array}$ & 6 & 26 & 8 & 61 & 101 \\
\cline { 3 - 7 } & $5,9 \%$ & $25,7 \%$ & $7,9 \%$ & $60,4 \%$ & $100 \%$ \\
\hline \multirow{2}{*}{3.} & $\begin{array}{l}\text { TELKOM transparan dalam memberikan } \\
\text { informasi tentang produknya }\end{array}$ & 71 & 17 & 3 & 10 & 101 \\
\cline { 3 - 7 } & $70,3 \%$ & $16,8 \%$ & $3 \%$ & $9,9 \%$ & $100 \%$ \\
\hline
\end{tabular}

Tabel 1. Indikator Pemenuhan Informasi

Berdasarkan pada pemaparan tabel diatas, temuan data menunjukkan mayoritas pelanggan bersetuju bahwa Telkom memberikan informasi sesuai dengan kebutuhan pelanggan dan dapat memberikan pemenuhan informasi kepada pelanggan (60,4\%). Akan tetapi, berkaitan dengan transparansi dalam memebrikan informasi berkaitan dengan produk Telkom, mayoritas pelanggan mengatakan bahwa Telkom tidak transparan untuk hal tersebut $(70,3 \%)$
Tabel 2 berkaitan dengan kejujuran dari Telkom. Pada indikator ini mayoritas pelanggan memberikan jawaban yang bernada negative. Sebanyak 63, 3\% pelanggan sangat tidak setuju bahwa Telkom dapat dipercaya dalam memberikan informasi tentang produknya. Selanjutnya, lebih dari $50 \%$ pelanggan mengatakan sangat tidak setuju tentang kebenaran informasi yang diberikan oleh Telkom.

\begin{tabular}{|c|l|c|c|c|c|c|}
\hline No. & \multicolumn{1}{|c|}{ Pernyataan } & STS & TS & S & SS & Total \\
\hline \multirow{2}{*}{1.} & TELKOM dapat dipercaya dalam & 69 & 14 & 4 & 14 & 101 \\
\cline { 3 - 7 } & memberikan informasi tentang produknya & $68,3 \%$ & $13,9 \%$ & $4 \%$ & $13,9 \%$ & $100 \%$ \\
\hline \multirow{2}{*}{2.} & $\begin{array}{l}\text { Semua informasi yang diberikan } \\
\text { TELKOM kepada pelanggan adalah benar } \\
\text { adanya }\end{array}$ & 61 & 23 & 4 & 13 & 101 \\
\cline { 3 - 7 } & $60,4 \%$ & $22,8 \%$ & $4 \%$ & $12,9 \%$ & $100 \%$ \\
\hline \multirow{2}{*}{3.} & $\begin{array}{l}\text { TELKOM dapat diandalkan dalam } \\
\text { memenuhi janji kepada pelanggan }\end{array}$ & 58 & 27 & 4 & 12 & 101 \\
\cline { 3 - 7 } & $57,4 \%$ & $26,7 \%$ & $4 \%$ & $11,9 \%$ & $100 \%$ \\
\hline
\end{tabular}

Tabel 2 Indikator Kejujuran

Indikator terakhir pada dimensi Integritas ini berkaitan dengan kehandalan. Tabel 3 menunjukkan bahwa 58,4\% dan $56,4 \%$ pelanggan masih mempercayai bahwa Telkom dapat diandalkan sebagai perusahaan informasi dan komunikasi, begitupula sebagai perusahaan yang selalu menjaga reputasinya. Akan tetapi, pelanggan membrikan respon negatif berkaitan dengan tanggung jawab Telkom kepada semua pelanggan $(58,4 \%)$. 


\begin{tabular}{|c|l|c|c|c|c|c|}
\hline No. & \multicolumn{1}{|c|}{ Pernyataan } & STS & TS & S & SS & Total \\
\hline \multirow{2}{*}{1.} & TELKOM dapat diandalkan sebagai & 13 & 17 & 12 & 59 & 101 \\
\cline { 3 - 7 } & perusahaan Informasi dan Komunikasi & $12,9 \%$ & $16,8 \%$ & $11,9 \%$ & $58,4 \%$ & $100 \%$ \\
\hline \multirow{2}{*}{2.} & $\begin{array}{l}\text { TELKOM selalu menjaga reputasinya } \\
\text { sebagai perusahaan Informasi dan }\end{array}$ & 14 & 13 & 17 & 57 & 101 \\
\cline { 2 - 7 } & Komunikasi di Indonesia & $13,9 \%$ & $12,9 \%$ & $16,9 \%$ & $56,4 \%$ & $100 \%$ \\
\hline \multirow{2}{*}{3.} & $\begin{array}{l}\text { TELKOM bertanggungjawab kepada } \\
\text { semua pelanggan }\end{array}$ & 59 & 15 & 12 & 15 & 101 \\
\cline { 3 - 7 } & $58,4 \%$ & $14,9 \%$ & $11,9 \%$ & $14,9 \%$ & $100 \%$ \\
\hline
\end{tabular}

Tabel 3 Indikator Kehandalan ${ }^{\mathrm{i}}$

Mengacu pada temuan data tersebut, sebagian besar pelanggan menganggap jika Telkom dapat memenuhi kebutuhan informasi. Hal tersebut sangat baik mengingat yang dikatakan Jordan (2006) bahwa kepercayaan (non transaksional) seperti memberikan informasi dapat dijadikan acuan sebagai kesuksesan dalam kegiatan bisnis perusahaan.

Pada indikator kejujuran, sebagian besar pelanggan sepakat bahwa Telkom tidak memiliki kredibilitas maupun transparansi dalam memberikan informasi. Anggapan tersebut dapat berakibat buruk bagi Telkom, Rawlins (2007) mengungkapkan jika kredibilitas dan kebenaran pesan yang disampaikan perusahaan memiliki peran penting dalam menjalin hubungan antara perusahaan dengan publiknya. Ketidakpercayaan pelanggan akan pesan yang diberikan Telkom sama halnya merusak integritas perusahaan yang berarti sama halnya dengan merusak kepercayaan yang telah dibangun (Somera \& Holt, 2015).
Rawlins (2007) menjelaskan jika kepercayaan harus diukur dan dimasukkan sebagai indikator penting bagi setiap perusahaan yang berkaitan dengan hubungan stakeholder dan reputasi. Pada penelitian ini sejatinya tidak diperuntukkan untuk melihat hubungan antara stakeholder dan reputasi, akan tetapi ditemukan data bahwa sebagian besar pelanggan menganggap Telkom selalu menjaga reputasinya. Berdasarkan hasil tersebut dapat disimpulkan bahwa sebagian besar pelanggan memiliki tingkat kepercayaan pada dimensi integritas adalah sedang, berkaitan dengan pemenuhan, kejujuran, dan kehandalan seperti yang ditunjukkan tabel dibawah ini:

\begin{tabular}{|c|l|c|c|}
\hline No. & Skala & Frekuensi & Persentase \\
\hline 1. & Tinggi & 16 & $15,8 \%$ \\
\hline 2. & Sedang & 63 & $62,4 \%$ \\
\hline 3. & Rendah & 22 & $21,8 \%$ \\
\hline \multicolumn{2}{|c|}{ Total } & 101 & $100 \%$ \\
\hline
\end{tabular}

Tabel 4 Tingkat Integritas

Menurut Charles Handy seperti yang dikutip Oetomo (2008) menyebutkan jika 
kepercayaan dapat dibangun dengan seven rules of trust, berkaitan dengan hal tersebut ada dua dari data temuan penelitian yang dianggap tidak memenuhi kriteria. Rules pertama yang dianggap tidak memenuhi kriteria adalah trust need boundaries, bahwa sebuah kepercayaan dapat dibangun dengan adanya komitmen dan kemampuan yang harus dimiliki perusahaan. Pada penelitian ini ditemukan data bahwa lebih dari setengah pelanggan menganggap Telkom tidak dapat memenuhi janji maupun tanggung jawabnya sebagai perusahaan penyedia jasa IndiHome. Hal tersebut dapat diartikan bahwa Telkom tidak dapat memberikan bukti nyata atas janji dan tanggung jawabnya kepada para pelanggan.

Rules selanjutnya yang dianggap tidak memenuhi kriteria adalah trust is tough yang dimaksudkan bahwa perusahaan harus berhati-hati dalam membangun kepercayaan. Menjalin dan menjaga perusahaan tidaklah semudah mengembalikan telapak tangan, butuh waktu dan proses panjang yang sulit. Hal tersebut dapat dikatakan demikian karena berdasarkan data yang diperoleh, lebih dari setengah pelanggan menganggap Telkom tidak memenuhi kejujuran dalam hal pemberian informasi. Kejujuran itu sendiri merupakan salah satu indikator dari integritas, yang mana bila kejujuran tersebut tidak dapat dipenuhi maka sama halnya dengan rusaknya integritas, yang dapat disimpulkan dapat merusak kepercayaan yang telah dibangun.

\section{KESIMPULAN}

Adanya petisi online maupun tanggapan dari pihak Telkom berupa kebijakan dapat diyakini memiliki dampak bagi masing-masing pihak, salah satunya kepercayaan. Kepercayaan itu sendiri memiliki peran penting penting bagi perusahaan. Berlandaskan dari konsep, penelitian ini pada dasarnya hanya digunakan untuk melihat tingkat kepercayaan pelanggan berdasarkan integritas yang dimiliki oleh Telkom. Integritas di dalam penelitian ini memiliki tiga indikator, yaitu pemenuhan informasi, kejujuran, dan kehandalan.

Berdasarkan temuan dan analisis data, tingkat kepercayaan pelanggan pada Telkom jika dikaitkan dengan integritas dapat diketahui berada pada tingkat sedang. Sekalipun demikian salah satu indikator integritas, yakni kejujuran memiliki penilaian negatif paling tinggi bila dibandingkan dengan indikator pemenuhan informasi maupun kehandalan. 


\section{DAFTAR PUSTAKA}

Budiargo, Dian. 2015. Berkomunikasi ala Net Geberation. Jakarta: PT. Elex Media Komputindo Kompas Gramedia.

Jordan, Edward J. 2006. Essentials of Public relations Management. UK: Burnham Publishers Book

Kim, Dan J., \& Donald L Ferrin. 2003. Antecedents of Consumer Trust in Bto-C Electronic Commerce. https://www.researchgate.net/publicat ion/220893427

Laksamana, Agung. 2015. Profesi Public relations dalam Era Digital. Jurnal Public relations Indonesia.

Mayer, Roger C., James H. Davis \& F. David Schoorman. 1995. An Integrative Model of Organizational Trust. The Academy of Management Review, Vol. 20, No. 3. http://www.jstor.org/stable/258792

Nova, Firsan. 2014. PR War: Pertaruhan Mengalahkan Krisis, Menaklukan Media, dan Memenangi Simpati Publik. Jakarta: Grasindo.

Oetomo, Budi Sutedjo., et al. 2008. i-CRM Membina Relasi dengan Pelanggan.Com. Jakarta: Andi Publisher.

Paliszkiewicz, Joanna., \& Bogdan Klepacki. 2013. Tools of Building Customer Trust. Warsaw University of Life Sciences.

Payne, Adrian. 2012. Handbook of CRM: Achieving Excellence in Customer Management. Oxford: Elsevier.

Rawlins, Brad L. 2007. Trust and PR Practice. 2007, Institute for Public relations. www.instituteforpr.org

Somera, Keya., \& M. Kenneth Holt. 2015. Integrity in Business: An Evaluation of Integrity across German and American Culture. International
Journal of Business and Social Science, Vol. 6, No.2

http://www.internetworldstats.com/asia.htm (diakses pada 28 September 2016, pukul 20:32 WIB. 